\title{
Inorganic carbon shortage may limit the development of submersed macrophytes in habitats of the Paraná River basin
}

\author{
Baixas concentraçóes de carbono inorgânico podem limitar o desenvolvimento \\ de macrófitas submersas em habitats do alto rio Paraná
}

\section{Aline de Freitas and Sidinei Magela Thomaz}

Núcleo de Pesquisas em Limnologia e Aquicultura - NUPELIA, Departamento de Biologia, Universidade Estadual de Maringá - UEM, Av. Colombo, 5790, CEP 87020-900, Maringá, PR, Brazil e-mail: e-mail: aline_de_freitas@hotmail.com; smthomaz@nupelia.uem.br

\begin{abstract}
Aim: In this investigation we carried out an experiment to assess whether the growth of Egeria najas and E. densa (two rooted submersed Hydrocharitacea, native to South America) are limited by inorganic carbon or not; Methods: We measured the early plant growth in $3 \mathrm{~L}$ microcosms with alkalinities of $100 \mu \mathrm{M} . \mathrm{L}^{-1}$ and $500 \mu \mathrm{M} . \mathrm{L}^{-1}$. These alkalinites represent extremes which are typical of most waters in the Upper Paraná River basin and they represent low and high inorganic carbon (mainly bicarbonate) availabilities, respectively; Results: The elongation of $E$. densa, and the relative growth rates and root development of both species were significantly higher when they grew in the high alkalinity treatment; Conclusions: Our results strongly suggest that in several habitats and during certain periods of the year, inorganic carbon shortage may limit the growth of both species. In this sense, phosphorus and nitrogen may assume a secondary role as controlling factors of these plants, because they assimilate these nutrients from sediment, where they are usually found in high concentrations. Thus, controlling eutrofication as a strategy to reduce their biomass may not be successful.
\end{abstract}

Keywords: eutrophication, reservoirs, Egeria, bicarbonate, aquatic plants.

Resumo: Objetivos: Nesse trabalho nós realizamos um experimento para avaliar se o crescimento de Egeria najas e $E$. densa (duas espécies de macrófitas aquáticas submersas da família Hydrocharitaceae, nativas da América do Sul) é limitado por carbono inorgânico; Métodos: Nós medimos os estágios iniciais de crescimento de fragmentos em microcosmos de $3 \mathrm{~L}$ com alcalinidade de $100 \mu \mathrm{M} . \mathrm{L}^{-1}$ e $500 \mu \mathrm{M} . \mathrm{L}^{-1}$. Esses valores de alcalinidade foram escolhidos por representarem extremos típicos da maioria dos ecossistemas aquáticos da bacia do Alto rio Paraná e representaram baixa e alta disponibilidade de carbono (principalmente bicarbonato), respectivamente; Resultados: $\mathrm{O}$ alongamento de $E$. densa e o crescimento relativo e desenvolvimento de raízes de ambas as espécies foram significativamente maiores quando os fragmentos cresceram no tratamento de alta alcalinidade; Conclusóes: Esses resultados indicam que em vários habitats da bacia do rio Paraná e durante certos períodos do ano, baixas concentrações de carbono inorgânico podem limitar o crescimento de ambas as espécies. Dessa forma, o fósforo e o nitrogênio podem assumir um papel secundário como fatores controladores do estabelecimento e crescimento dessas plantas, porque elas assimilam esses nutrientes do sedimento, onde os mesmos são encontrados em elevadas concentrações. Assim, somente o controle da eutrofização como uma estratégia para reduzir a biomassa dessas espécies pode não alcançar sucesso.

Palavras-chave: eutrofização, reservatórios, Egeria, bicarbonato, plantas aquáticas. 


\section{Introduction}

Egeria najas Planchon and Egeria densa Planchon are two rooted submersed macrophytes of the family Hydrocharitaceae with similar architectures (Cook and Urmi-Köning, 1984). They are native to South America where they colonize rivers, lakes and reservoirs (Bini and Thomaz, 2005; Martins et al., 2008; Sousa et al., 2010). These macrophytes are important components of aquatic ecosystems because they provide refuge and feeding resources for aquatic fauna (Pelicice and Agostinho, 2006), in addition to other ecosystem benefits. These species may grow prolifically especially in less turbid reservoirs, whence they may hamper energy production (Marcondes et al., 2003).

The variables that limit the colonization and growth of these two species of macrophytes are scarcely known. Evidences in the field, in subtropical rivers and in reservoirs, suggest that temperature, underwater radiation and inorganic carbon are important determinants of their success (Bini and Thomaz, 2005; Camargo et al., 2006; Thomaz, 2006; Sousa et al., 2010). Indeed, experiments indicated that at least for $E$. najas, nutrients such as phosphorus and nitrogen are less important because they are abundant in sediments, where these plants obtain most of their requirements (Thomaz et al., 2007).

Carbon dioxide is the main source of inorganic carbon used by submersed macrophytes (SandJansen, 1983). However, most of the freshwater ecosystems have $\mathrm{pH}$ of $-6-8$ and in these conditions $\mathrm{CO}_{2}$ can be depleted to near zero due to higher photosynthesis by micro-algae and macrophytes (Esteves, 1998). Thus, inorganic carbon may limit submersed macrophytes growth due to its scarcity and slow diffusion in water (Madsen and Sand-Jensen, 1991). Submersed macrophytes have developed biochemical and morphological strategies to overcome this limitation and the use of bicarbonate $\left(\mathrm{HCO}_{3}^{-}\right)$is the most common one (Allen and Spence, 1981; Bowes, 1985; SandJansen and Gordon, 1986; Pierini and Thomaz, 2004). Because bicarbonate predominates over carbon dioxide at $\mathrm{pH}$ values of $-6.5-8.0$, typical of most inland waters, species that employ this strategy have a competitive advantage over others lacking this ability. Indeed, alkalinity (which directly corresponds to bicarbonate concentrations) is an important determinant of distribution and composition of submersed macrophytes in freshwater ecosystems (Vestergaard and SandJansen, 2000).
Positive influence of alkalinity on the occurrences of $E$. najas and $E$. densa were first suggested in the Paraná River basin in an investigation carried out in several reservoirs (Bini and Thomaz, 2005; Thomaz, 2006). Experiments also showed that the photosynthesis of both species responds positively to increasing alkalinity (Pierini and Thomaz, 2004). However, whether biomass accumulation of these species responds positively or not to alkalinity is still an open question. In this work we experimentally investigated the effects of carbon availability, manipulating the alkalinity, on the initial growth of $E$. najas and $E$. densa. We hypothesized that both species grow faster in higher values of alkalinity, compared to lower ones. Because the alkalinities we used are within the range obtained in several natural and artificial aquatic habitats of the Paraná basin, our results serve the purpose to test whether carbon availability limits these two species in this basin or not.

\section{Material and Methods}

Samplings were carried out in March 2003 in the Rosana Reservoir (Paranapanema River). Macrophytes were collected in several points to maximize the variability of the macrophyte populations. Water and sediment were obtained inside patches of macrophytes in the same reservoir.

We selected $10 \mathrm{~cm}$-apical portions of healthy plants and planted them in $50 \mathrm{~mL}$ plastic cups containing sediment. Each individual remained inside a $3 \mathrm{~L}$ aquarium. All aquaria were randomized inside a germination chamber with 12 hours photoperiod, at $25^{\circ} \mathrm{C}$ and with PAR of ca. $170 \mu \mathrm{M} . \mathrm{m}^{-2} / \mathrm{s}$.

We performed two treatments $\left(100 \mu \mathrm{M} . \mathrm{L}^{-1}\right.$ and $500 \mu \mathrm{M} . \mathrm{L}^{-1}$; hereafter low alkalinity - LA and high alkalinity - HA) and each treatment was replicated five times. These concentrations were chosen because they represent the extreme values found in several habitats, including lakes and reservoirs of the Upper Paraná River basin (Thomaz et al., 2004; Pagioro et al., 2005). The water used in the experiment was filtered with plankton net to eliminate bigger organisms and debris. Alkalinities were adjusted with $1.0 \mathrm{M} \mathrm{NaHCO}_{3}^{-}$solution. Water samples were measured weekly for alkalinity (gran titration; (Carmouze, 1994)). When necessary, the $\mathrm{NaHCO}_{3}$ - solution was used to adjust the values to the ones chosen for each treatment.

The initial dry weight values of the fragments were calculated using regressions between dry and fresh weight, obtained with independent samples 
of each species of macrophytes. Dry weight was measured after drying biomass in an oven at $60{ }^{\circ} \mathrm{C}$ until constant weight.

After 14 days (E. najas) and 21 days (E. densa) the following variables were measured: plant length $(\mathrm{cm})$, above-ground tissues dry weight and root dry weight $(\mathrm{g})$. Periods differed between species because E. najas apparently stopped growing and started to exhibit chlorosis after two weeks.

Relative growth rates $(R G R)$ for above-ground biomass (photosynthetic tissues) were determined with dry weight results using the Equation 1:

$\mathrm{RGR}=\left(\ln \mathrm{W}_{2}-\ln \mathrm{W}_{1}\right) / \Delta \mathrm{t}$

where $\mathrm{W}_{2}$ is the final dry mass, $\mathrm{W}_{1}$ the initial mass and $\Delta \mathrm{t}$ is the number of days.

The effects of treatments (LA and HA) on response variables (plant length, above-ground tissues $R G R$ and root dry weight) were tested with a $t$ test. However, normality and homoscedasticity were not reached for $E$. najas root dry weight, and thus we applied a Mann-Whitney test to assess for differences of this variable. Although our first intention was also to compare species, what would require a two-way Anova, this was not possible in view of different incubation periods between the two species.

\section{Results}

After 14 days of investigation, the mean increase in the above-ground dry weight per fragment of $E$. najas was of $0.045 \mathrm{~g}( \pm 0.017 \mathrm{SD})$ in the LA treatment and of $0.088 \mathrm{~g}( \pm 0.028 \mathrm{SD})$ in the HA treatment. For $E$. densa, after 21 days of incubation, the mean increases in dry weight were of $0.032 \mathrm{~g}( \pm 0.012 \mathrm{SD})$ in the LA treatment and of $0.105 \mathrm{~g}( \pm 0.009 \mathrm{SD})$ in the HA treatment.

Alkalinity affected all variables in both species, except the $E$. najas length which did not differ significantly between treatments $(T=-0.059$; $\mathrm{P}=0.954$; Figure 1a). E. najas above-ground biomass $R G R$ was almost twice higher in the HA $\left(\right.$ mean $\left.=0.0054 \mathrm{~d}^{-1}\right)$ than in the LA treatment $\left(0.0028 \mathrm{~d}^{-1}\right)(\mathrm{T}=-3.349 ; \mathrm{P}=0.01$; Figure $1 \mathrm{~b})$. Plants growing in the HA treatment developed almost five times more roots than those growing in the LA one (0.014 and 0.090 g.plant ${ }^{-1}$, respectively) $(\mathrm{T}=-2.302 ; \mathrm{P}=0.02$; Figure $1 \mathrm{c})$.

Egeria densa elongated slightly more in the HA than in the LA treatment (Figures 2 and 3a), and differences were significant $(\mathrm{T}=-5.087 ; \mathrm{P}<0.001)$. Above-ground biomass $R G R$ for this species was also higher in the former $\left(0.0040 \mathrm{~d}^{-1}\right)$ compared to the latter treatment $\left(0.0013 \mathrm{~d}^{-1}\right)$ (Figure $\left.3 \mathrm{~b}\right)$, and the same occurred for root development (0.016 and 0.007 g.plant ${ }^{-1}$ at the HA and LA, respectively) (Figure 3c). For both variables differences were significant: $\mathrm{F}=-9.215 ; \mathrm{P}<0.001$ for plant $R G R$ and $\mathrm{F}=-4.231 ; \mathrm{P}<0.001$ for root dry weight.

\section{Discussion}

There are evidences obtained in situ (e.g., Sand-Jansen and Gordon, 1986) and in the lab (e.g. Pierini and Thomaz 2004) that several species of macrophytes (including our target species
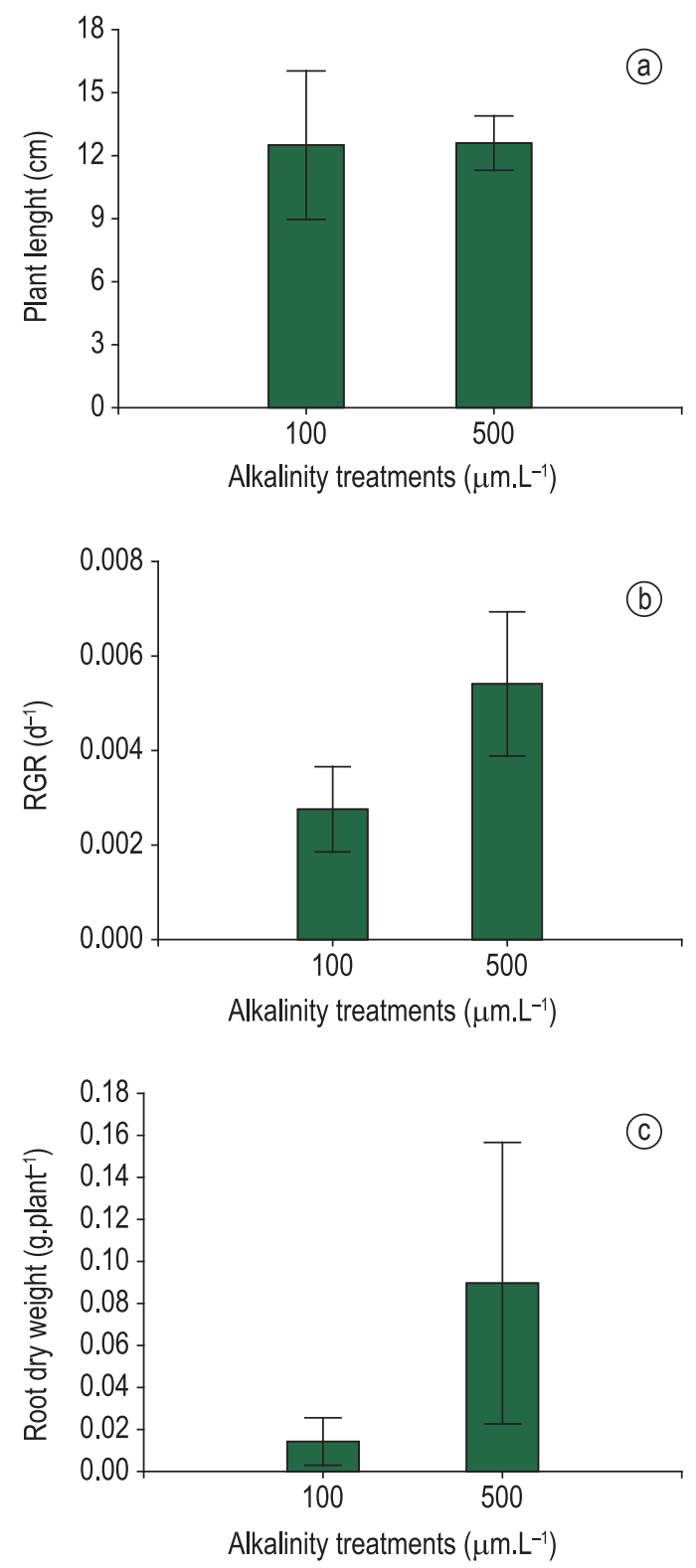

Figure 1. Mean values $( \pm \mathrm{SD})$ of Egeria najas length (a), above-ground relative growth rates (b) and root dry weight (c) after 14 days growing in low $\left(100 \mu \mathrm{M} . \mathrm{L}^{-1}\right)$ and high $\left(500 \mu \mathrm{M} . \mathrm{L}^{-1}\right)$ alkalinities. 


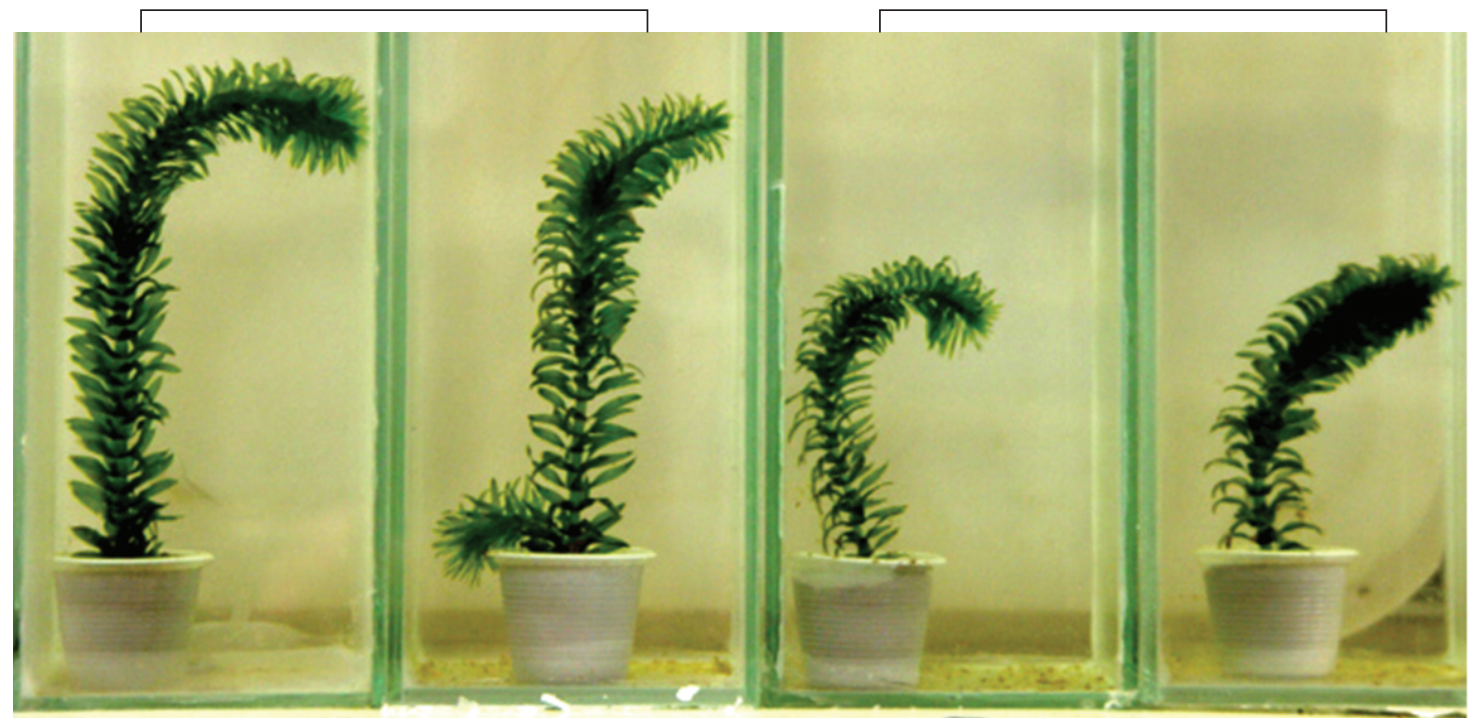

Figure 2. Picture of $E$. densa, after 21 days growing in two alkalinity treatments.

E. najas and $E$. densa) increase the photosynthetic rates with increasing alkalinity. Thus, differently from free-floating and emergent species, which depend more on phosphorus and nitrogen for growth (Henry-Silva et al., 2008), alkalinity has been considered as an important variable explaining patterns of occurrence of submersed species (Vestergaard and Sand-Jensen, 2000). These results may be partially explained by the ability these plants have to assimilate bicarbonate, which represents an alternative source of inorganic carbon (Sand-Jansen and Gordon, 1986). This mechanism was suggested by our experiments for both species of macrophytes, since they grew faster (both in terms of photosynthetic tissues as well as root formation) when growing in the HA, compared to the LA treatment.

Our experiments corroborated the observations carried out in reservoirs of the Paraná basin, which indicate that the greatest development of submersed species occurs in those reservoirs located in the Paranapanema River, which have the highest values of alkalinity (Thomaz, 2006). In fact, alkalinity values in these reservoirs are near $500 \mu \mathrm{M} . \mathrm{L}^{-1}$ during the dry period (Pagioro et al., 2005), which is comparable with our high alkalinity treatment. On the other hand, alkalinity values lower than $200 \mu \mathrm{M} . \mathrm{L}^{-1}$ were recorded in 14 reservoirs during the dry period, and in 20 reservoirs during the rainy period (Pagioro et al., 2005). Similarly, several natural habitats of the Paraná River basin have alkalinities lower than $100 \mu \mathrm{M} . \mathrm{L}^{-1}$ (Thomaz et al., 2004). Thus, data obtained in several natural habitats together with our experimental results strongly indicate that alkalinity (a surrogate of the inorganic carbon availability) can be a limiting factor for the growth of E. najas and E. densa in the majority of the freshwater ecosystems of the Paraná basin, at least during certain periods of the year.

Other in situ observations indicate that $\mathrm{CO}_{2}$ is depleted inside patches of submersed macrophytes mainly during certain periods of the day when photosynthesis and $\mathrm{pH}$ are high (Jones et al., 1996; Esteves, 1998). Under these conditions the species which are able to use bicarbonate have a competitive advantage over those which use only $\mathrm{CO}_{2}$. This advantage can also explain the great spread of $E$. najas and $E$. densa in different habitats of the Paraná River basin, such as the Rosana Reservoir (Paranapanema River), Jupiá, Porto Primavera and Itaipu reservoirs (Paraná River) and lateral channels and floodplain lakes of the Paraná River (Marcondes et al., 2003; Martins et al., 2008; Sousa et al., 2010).

Comparing both species, our experiments showed that when growing in the LA treatment, E. najas accumulated ca. $50 \%$ more dry weight in the above-ground tissues and ca. 60\% more dry weight in roots than $E$. densa, even though the experiment carried out with the first species was shorter than with the second. Although we were not able to employ any statistical analysis to compare both species in view of the differences in the experiments duration (see reasons in Methods), these results indicate that $E$. najas would be a more successful species in habitats with low alkalinity, at 

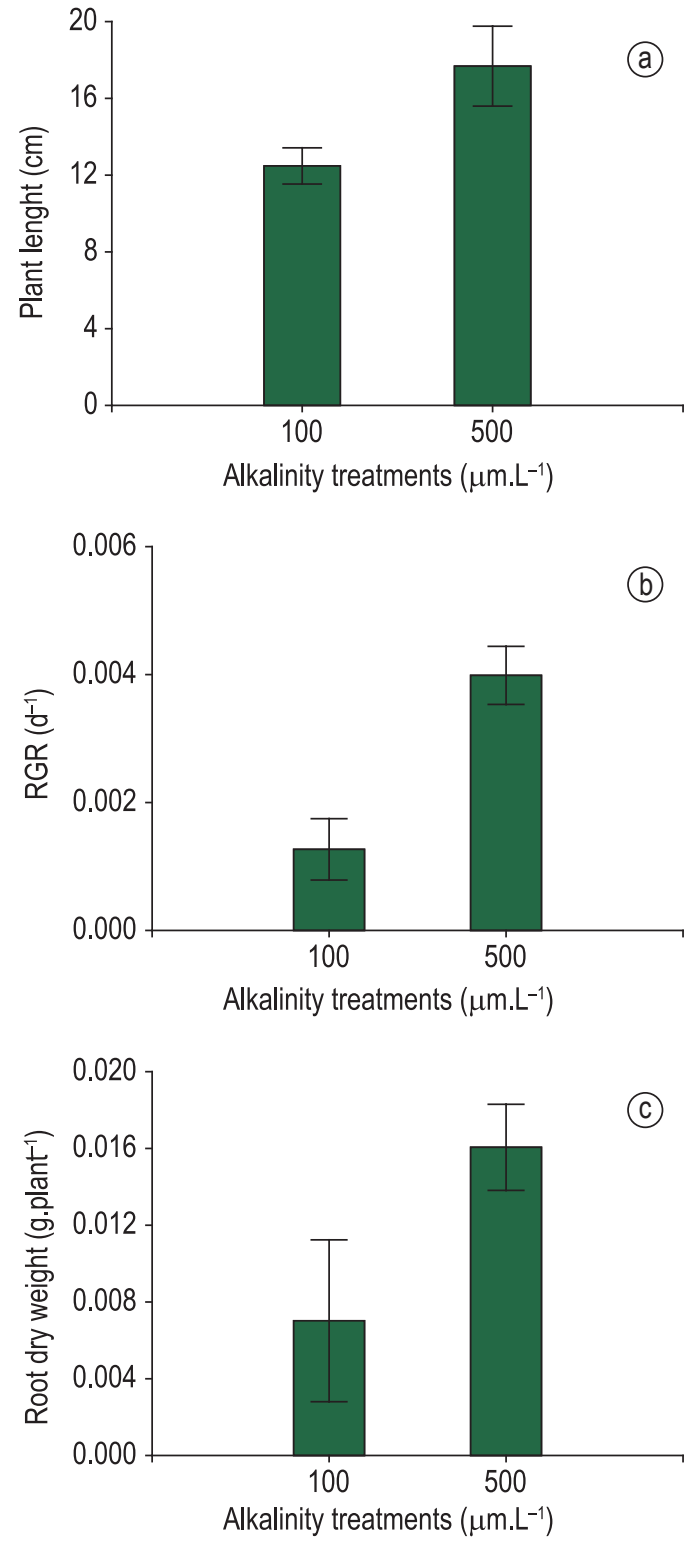

Figure 3. Mean values $( \pm S D)$ of Egeria densa length (a), above-ground relative growth rates (b) and root dry weight (c) after 21 days growing in low $\left(100 \mu \mathrm{M} . \mathrm{L}^{-1}\right)$ and high $\left(500 \mu \mathrm{M} . \mathrm{L}^{-1}\right)$ alkalinities.

least in the early stages of development. However, because our data refer to the stage of growth and colonization, they can not be extrapolated to adult plants. Long term experiments carried out in larger mesocosms are necessary to infer which species is more successful in aquatic ecosystems with different alkalinities and about their patterns of distribution in nature.

Several investigations have shown that submersed macrophytes obtain most of phosphorus and nitrogen requirements from the sediment (e.g., Carignan and Kalff, 1980; Carr and Chambers,
1998). At least for E. najas, it has been shown experimentally that these elements do not limit its development in habitats of the Paraná basin (Thomaz et al., 2007). Giving the similarity between this species and its congener E. densa, it is probable that the latter also use the sediment as the main source of nutrients. Thus, the results obtained in our experiments strongly suggest that inorganic carbon is probably a more important limiting factor for growth of these two species than phosphorus and nitrogen. If true, efforts to reduce the growth of these two plants by only controlling eutrophication may be unsuccessful.

\section{Acknowledgements}

We thank R.P. Mormul for critical review and helping in the statistical analyses, M. Teixeira for criticism and English corrections, and M. J. Silveira for comments of a first draft. A. Freitas acknowledges the Brazilian Council of Research (CNPq) for providing grants. S.M. Thomaz is also thankful to this agency for continuous funding through a Research Productivity Grant, which provided partial resources to carry out this investigation. Complementary funds were provided by Itaipu Binacional.

\section{References}

ALLEN, ED. and SPENCE, DHN. 1981. The differential ability of aquatic plants to utilize the inorganic carbon supply in fresh waters. New Phytologist, vol. 87, p. 269-283. http://dx.doi. org/10.1111/j.1469-8137.1981.tb03198.x

BINI, LM. and THOMAZ, SM. 2005. Prediction of Egeria najas and Egeria densa occurrence in a large subtropical reservoir (Itaipu Reservoir, BrazilParaguay). Aquatic Botany, vol. 83, p. 227-238. http://dx.doi.org/10.1016/j.aquabot.2005.06.010

BOWES, G. 1985. Pathways of $\mathrm{CO}_{2}$ fixation by aquatic organisms. In LUCAS, WJ. and BERRY, J., eds. A. Inorganic carbon uptake by aquatic photosynthetic organisms. Rockville: Soc. Plant Physiol. p. 187-210.

CAMARGO, AFM., PEZZATO, MM., HENRY-SILVA, GG. and ASSUMPÇÃO, AM. 2006. Primary production of Utribularia foliosa L., Egeria densa Planchon and Cabomba furcata Schult \& Schult from rivers of the coastal plain of the State of Sáo Paulo, Brazil. Hydrobiologia, vol. 570, p. 35-39.

CARIGNAN, R. and KALLF, J. 1980. Phosphorus sources for aquatic weeds - water or sediments? Science, vol. 207, p. 987-989. http://dx.doi. org/10.1126/science.207.4434.987

CARMOUZE, JP. 1994. O metabolismo dos ecossistemas aquáticos. São Paulo: Edgard Blucher/SBL/FAPESP. 
CARR, GM. and CHAMBERS, PA. 1998. Macrophyte growth and sediment phosphorus and nitrogen in a canadian prairie river. Freshater Biology, vol. 39, p. 525-536.

COOK, CDK. and URMI-KÖNING, K. 1984. A revision of genus Egeria (Hydrocharitaceae). Aquatic Botan y, vol. 19, p. 73-96. http://dx.doi. org/10.1016/0304-3770(84)90009-3

HENRY-SILVA, GG., CAMARGO, AFM. and PEZZATO, MM. 2008. Growth of free-floating aquatic macrophytes in different concentrations of nutrients. Hydrobiologia, vol. 610, p. 153-160. http:// dx.doi.org/10.1007/s10750-008-9430-0

JONES, JI., HARDWOCK, K. and EATON, JW. 1996. Diurnal carbon restrictions on the photosynthesis of dense stands of Elodea nuttalli (Planch.) St. John. Hydrobiologia, vol. 340, p. 11-16. http://dx.doi. org/10.1007/BF00012727

ESTEVES, FA. 1998. Fundamentos de limnologia. 2. ed. Rio de Janeiro: Interciência. 602 p.

MADSEN, TV. and SAND-JENSEN, K. 1991. Photosynthetic carbon assimilation in aquatic macrophytes. Aquatic Botany, vol. 41, p. 5-40. http:// dx.doi.org/10.1016/0304-3770(91)90037-6

MARCONDES, DAS., MUSTAFÁ, AL. and TANAKA, RH. 2003. Estudos para manejo integrado de plantas aquáticas no reservatório de Jupiá. In THOMAZ, SM. and BINI, LM., eds. Ecologia e Manejo de Macrófitas Aquáticas. Maringá: Eduem. p. 299-317.

MARTINS, D., COSTA, NV., TERRA, MA. and MARCHI, SR. 2008. Characterization of the aquatic plant communities of 18 reservoirs of five watersheds in Sao Paulo, Brazil. Planta Daninha, vol. 26, p. 17-32. http://dx.doi.org/10.1590/S010083582008000100003

PAGIORO, TA., THOMAZ, SM. and ROBERTO, MC. 2005. Caracterização limnológica abiótica dos reservatórios. In RODRIGUES, L., THOMAZ, SM., AGOSTINHO, AA. and GOMES, LC., eds. Biocenoses em reservatórios: padróes espaciais e temporais. Sáo Carlos: Rima. p. 17-37.

PELICICE, FM., and AGOSTINHO, AA. 2006. Feeding ecology of fishes associated with Egeria spp. Patches in a tropical reservoir, Brazil. Ecology of Freshwater Fish, vol. 15, p. 10-19. http://dx.doi. org/10.1111/j.1600-0633.2005.00121.x

PIERINI, SA. and THOMAZ, SM. 2004. Effects of inorganic carbon source on photosynthetic rates of Egeria najas Planchon and Egeria densa
Planchon (Hydrocharitaceae). Aquatic Botany, vol. 78, p.135-146. http://dx.doi.org/10.1016/j. aquabot.2003.09.007

SAND-JANSEN, K. 1983. Photosynthetic carbon sources of stream macrophytes. Journal of Experimental Botany, vol. 34, p. 198-210. http:// dx.doi.org/10.1093/jxb/34.2.198

SAND-JANSEN, K. and GORDON, DM. 1986. Variable $\mathrm{HCO}_{3}$ - affinity of Elodea canadensis Michaux in response to different $\mathrm{HCO}_{3}^{-}$and $\mathrm{CO}_{2}$ concentrations during growth. Oecologia, vol. 70, p. 426-432. http://dx.doi.org/10.1007/BF00379507

SOUSA, WTZ., THOMAZ., SM. and MURPHY, KJ. 2010. Response of native Egeria najas Planch. and invasive Hydrilla verticillata (L.f.) Royle to altered hydroecological regime in a subtropical river. Aquatic Botany, vol. 92, p. 40-48. http://dx.doi. org/10.1016/j.aquabot.2009.10.002

THOMAZ, SM., PAGIORO, TA., BINI, LM., ROBERTO, MC. and ROCHA, RRA. 2004. Limnological characterization of the aquatic environments and the influence of hydrometric levels. In THOMAZ, SM., AGOSTINHO, AA. and AHN, NS., eds. The Upper Paraná River and its floodplain: physical aspects, ecology and conservation. Leiden: Backhuys Publishers. p. 75-102.

THOMAZ, SM. 2006. Fatores que afetam a distribuição e o desenvolvimento de macrófitas aquáticas em reservatórios: uma análise em diferentes escalas. In NOGUEIRA, MG., HENRY, R. and JORCIN, A., eds. Ecologia de reservatórios. Impactos potenciais, açōes de manejo e sistemas em cascata. São Carlos: RiMa. p. 165-181.

THOMAZ, SM., PIERINI, SA., CHAMBERS, PA. and PEREIRA, G. 2007. Effects of phosphorus and nitrogen amendments on the growth of Egeria najas. Aquatic Botany, vol. 86, p. 191-196. http://dx.doi. org/10.1016/j.aquabot.2006.10.004

VESTERGAARD, O. and SAND-JENSEN, K. 2000. Aquatic macrophyte richness in Danish lakes in relation to alkalinity, transparency, and lake area. Canadian Journal of Fisheries and Aquatic Sciences, vol. 57, p. 2022-2031. http://dx.doi.org/10.1139/ f00-156 